\title{
Pembagian Masker Dan Hand Sanitizer Serta Sosialisasi Pencegahan Penyebaran Covid-19 Pada Masyarakat Dusun Banngoi Kabupaten Seram Bagian Timur
}

\author{
La Rakhmat Wabula*1, Ira Sandi Tunny ${ }^{2}$ \\ 1,2Program Studi Ilmu Keperawatan, STIKes Maluku Husada, Indonesia \\ *e-mail: la.rakhmat.wabula.stikesmh@gmail.com ${ }^{1}$, irasandi.99@gmail.com $^{2}$
}

\begin{abstract}
Abstrak
Pandemi Covid-19 merupakan masalah yang dialami secara global tidak terkecuali masyarakat Dusun Banggoi. Kasus positif Covid-19 di Dusun Banggoi Kabupaten Seram Bagian Timur masih relative tinggi dan terus bertambah. Hal ini mengakibatkan tingkat penularan Covid-19 semakin tinggi. Oleh karena itu, masalah ini perlu menjadi perhatian khusus agar secepatnya dilakukan penanganan penanggulangan penularan Covid-19. Fenomena terkait kesadaran masyarakat terhadap pentingnya mentaati protokol kesehatan masih sangat minim, seperti saat bepergian tidak menggunakan masker, tidak mencuci tangan, dan tidak menjaga jarak. Berdasarkan permasalahan tersebut, sehingga pentingnya melakukan suatu upaya yang dapat menyadarkan pola pikir masyarakat betapa pentingnya mematuhi protokol kesehatan, yaitu dengan melakukan kegiatan pembagian masker, sosialisasi pencegahan penyebaran Covid-19, pembuatan dan pemasangan tempat cuci tangan. Sosialisasi ini dilakukan di Dusun Banggoi Kabupaten Seram Bagian Timur. Adapun hasil kegiatan yang dicapai dari sosialisasi ini, yaitu masyarakat lebih peduli dalam mematuhi protokol kesehatan seperti memakai masker, menjaga jarak, dan mencuci tangan.
\end{abstract}

Kata kunci: cuci tangan, Covid-19, pembagian masker, penerapan 3M, sosialisasi

\begin{abstract}
The Covid-19 pandemic is a global problem, including for the people of Banggoi Hamlet. Positive cases of Covid-19 in Banggoi Hamlet, East Seram Regency are still relatively high and continue to grow. This has resulted in a higher rate of transmission of Covid-19. Therefore, this issue needs special attention so that the handling of Covid-19 transmission is immediately carried out. Phenomena related to public awareness of the importance of obeying health protocols are still very minimal, such as when traveling not wearing masks, not washing hands, and not keeping a distance. Based on these problems, it is important to make an effort that can make people aware of the importance of complying with health protocols, namely by distributing masks, socializing the prevention of the spread of Covid-19, making and installing handwashing stations. This socialization was carried out in Banggoi Hamlet, East Seram Regency. The results of the activities achieved from this socialization are that people are more concerned about complying with health protocols such as wearing masks, maintaining distance, and washing hands.
\end{abstract}

Keywords: application of 3M, Covid-19, distribution of masks, socialization, washing hands

\section{PENDAHULUAN}

Pada awal bulan Desember 2019 sejumlah pasien dengan penyakit tidak dikenal berdatangan ke Rumah Sakit Pusat Wuhan, Cina [1]. Penyakit yang menyebabkan radang paruparu tersebut diduga diakibatkan oleh virus yang berasal dari pasar ikan Huanan yang juga menjual binatang liar [2]. Setelah memasuki tahun 2020 otoritas Cina umumkan sebuah virus Covid-19 jenis baru. Korban meninggal berjatuhan hingga ribuan dan pasien di luar Cina juga dilaporkan semakin banyak. WHO telah menetapkan wabah Covid-19 sebagai pandemik global dan meminta semua komunitas dunia bekerja sama untuk mengakhiri masa-masa sulit ini [3].

Prevalensi Covid-19 per tanggal 06 Juni 2021, secara global terdapat 223 negara yang mengalami Covid-19, terkonfirmasi sebanyak 172.630.637 positif Covid-19, dan yang meninggal sejumlah 3.718.683 orang. Di Indonesia, yang terkonfirmasi positif Covid-19 sejumlah 1.856 .038 orang, sembuh sejumlah 1.705 .971 orang, dan meninggal sejumlah 51.612 orang. Jumlah prevalensi pasien Covid-19 di Provinsi Maluku sejumlah 7.793 (0,4\%) [4].

Kehadiran Covid-19 tentu berdampak pada permasalahan sosial dan terjadi hampir di seluruh dunia, karena pandemic Covid-19 yang merajalela kondisi dunia menjadi tidak stabil, 
tidak hanya mengatasi warga yang terpapar virus mematikan tersebut. Pemerintah melakukan upaya pencegahan penyebaran Covid-19, yaitu dengan sosialisasi 3M dan 3T. Istilah 3M merupakan protokol kesehatan yang perlu dilakukan setiap individu agar tidak tertular Covid-19, yakni memakai masker, mencuci tangan, dan menjaga jarak. Di sisi lain, untuk mengidentifikasi warga yang terpapar Covid-19, pemerintah mengistilahkan upaya 3T, yakni testing (pemeriksaan), tracing (penelusuran kontak), dan treatment (perawatan/isolasi) [5].

Sesuai informasi dari WHO dan Kementerian Kesehatan yang menyatakan bahwa Covid19 menyebar secara cepat melalui percikan droplet baik saat bersin/batuk maupun saat berbicara. Memakai masker menjadi salah satu cara efektif untuk menahan droplet yang menyebar saat seseorang sedang berbicara dan bersin atau batuk [6]. Terlebih masih ada orang tanpa gejala (OTG) di sekitar masyarakat yang belum melakukan isolasi dengan baik. Sehingga mewajibkan masyarakat memakai masker adalah upaya terbaik untuk menurunkan risiko penularan Covid-19 [7]. Selain memakai masker, menjaga jarak dan mencuci tangan juga turut menurunkan risiko penularan Covid-19, karena jika menerapkan cuci tangan pakai sabun, risiko penularan turun dari 35\% menjadi 65\% [8]. Memakai masker kain menurunkan risiko penularan menjadi $45 \%$, dengan memakai masker bedah risiko penularan turun 70\% [9]. Menjaga jarak minimal 1 meter dapat menurunkan risiko penularan hingga 85\% [10]. Maka, dengan menggabungkan memakai masker dengan benar, menjaga jarak dan mencucui tangan dengan sabun, risiko penularan Covid-19 semakin rendah.

Berdasarkan fenomena yang ada pada masyarakat Dusun Banggoi Kabupaten Seram Bagian Timur bahwa kesadaran masyarakat terhadap pentingnya mentaati protokol kesehatan masih sangat minim, seperti saat bepergian tidak menggunakan masker, tidak mencuci tangan, dan tidak menjaga jarak. Selain itu juga munculnya stigma di kalangan masyarakat bahwa Covid19 tidak ada, sehingga tidak perlu dikhawatirkan. Sehingga di dalam kehidupan sehari-hari masyarakat tidak mematuhi protokol kesehatan.

Langkah-langkah utama yang hendak dilaksanakan masyarakat agar dapat mengurangi dan mengantisipasi penyebaran Covid-19, yaitu seperti penggunaan masker, menutup mulut dan hidung saat bersin ataupun batuk, mencuci tangan secara teratur dengan sabun atau desinfeksi dengan pembersih tangan yang mengandung setidaknya $60 \%$ alcohol, menghindari kontak dengan orang yang terinfeksi, menjaga jarak dari orang-orang, dan menahan diri dari menyentuh mata, hidung, dan mulut dengan tangan yang tidak dicuci [11].

Tingkat disiplin masyarakat melaksanakan $3 \mathrm{M}$ atau protokol kesehatan mengalami penurunan di semua daerah. Tak ayal ini memicu peningkatan angka kasus aktif Covid-19. Tingkat disiplin masyarakat di hampir semua daerah mengalami penurunan [12]. Awal November 2020 lalu tingkat kepatuhan memakai masker ada di kisaran 86,18\%, tapi minggu-minggu selanjutnya mengalami penurunan. Angka disiplin sempat naik menjadi 81,65\%, tapi presentase kepatuhan masyarakat menggunakan masker kembali menurun menjadi 80,48\% pada 24 Desember 2020. Tingkat kepatuhan menjaga jarak yang di awal November ada di angka 81,87\%, lalu turun drastic di pertengan bulan dan pada 24 Desember 2020 ada di angka 76,87\% [13].

Pengetahuan dan tindakan yang nyata dari pemerintah dan masyarakat terkait PHBS akan mampu menurunkan jumlah kasus COVID-19, sehingga masa pandemi COVID-19 dapat berakhir dengan cepat [14]. Peran pemerintah harus tegas dalam menerapkan sanksi pidana dan pidana denda sebagai alternatif untuk membuat masyarakat jera, teredukasi dan sebagai sarana pengendalian sosial [15]. Berdasarkan fenomena tersebut, hal ini perlu disadari, pemerintah tidak bisa kerja sendiri. Perlu Gerakan massif melibatkan semua komponen masyarakat, terutama tokoh-tokoh nonformal yang dapat memberi pengaruh langsung ke masyarakat [16]. Oleh karena itu, kegiatan pengabdian masyarakat ini bertujuan untuk memberikan informasi terkait pentingnya sosialisasi pencegahan Covid-19 khususnya pada Masayarakat Dusun Banggoi Kabupaten Seram Bagian Timur. 


\section{METODE}

Metode yang dilakukan, yaitu melalui sosialisasi kepada masyarakat Dusun Banggoi Kabupaten Seram Bagian Timur terkait upaya pencegahan penyebaran Covid-19 dengan beberapa cara berikut:

a. Metode observasi lapangan, dilakukan untuk memetakan tempat dan lokasi pembagian masker dan hand sanitizer kepada masyarakat khususnya di Dusun Banggoi Kabupaten Seram Bagian Timur.

b. Sosialisasi kegiatan, dilakukan dengan mendatangani masyarakat secara langsung dari rumah ke rumah dan memberikan informasi terkait pentingnya penerapan 3M, serta membagikan masker dan hand sanitizer kepada masyarakat.

Berikut beberapa tahapan sosialisasi yang dilakukan oleh tim, sebagai berikut:

a. Tahap I (Observasi Lapangan)

Tim pengabdian melakukan kegiatan observasi lapangan yaitu di Dusun Banggoi Kabupaten Seram Bagian Timur untuk memetakan tempat dan lokasi pembagian masker dan hand sanitizer kepada masyarakat.

b. Tahap II (Kegiatan Perizinan)

Tim Pengabdian meminta izin kepada Kepala Dusun Banggoi terkait kegiatan sosialiasi yang akan dilaksanakan. Sosialisasi ini bertujuan untuk memberikan gambaran tentang disiplin protokol kesehatan Covid-19 sekaligus pembagian masker dan hand sanitizer kepada masyarakat.

c. Tahap III (Kegiatan Sosialisasi)

Sosialisasi disiplin protokol kesehatan Covid-19 dilakukan pada hari Sabtu-Minggu, 27-28 Maret 2021. Sosialisasi dilakukan dengan tetap memperhatikan protokol kesehatan, menggunakan masker, menerapkan kebiasaan cuci tangan dan penggunaan hand sanitizer, serta pembatasan jarak sosial. Sosialisasi yang dilaksanakan oleh tim dilakukan dengan mendatangi dari rumah ke rumah dengan beberapa kelompok tim. Jadi setiap rumah didatangi oleh tim agar kegiatan sosialisasi dapat berjalan secara efektif dan efisien.

\section{HASIL DAN PEMBAHASAN}

Kegiatan sosialisasi ini dilaksanakan pada hari Sabtu-Minggu, 27-28 Maret 2021. Kegiatan dilaksanakan sesuai dengan metode pelaksanaan yang telah dipaparkan sebelumnya, kegiatan sosialisasi ini dilakukan melalui 3 tahapan dengan beberapa program utama, yaitu: sosialisasi upaya pencegahan penyebaran Covid-19, pembagian leaflet, pembagian masker, pembagian hand sanitizer dan pembuatan tempat hand sanitizer.

Kegiatan dilaksanakan dengan tetap mematuhi protokol kesehatan 3M. Adapun pembagian tim menjadi 4 kelompok, dimana setiap kelompok terdiri dari 5 mahasiswa. Metode penyuluhan dilakukan melalui ceramah. Kemudian dilakukan pemberian masker, hand sanitizer dan leaflet kepada setiap rumah dan jalan raya yang berada di Dusun Banggoi Kabupaten Seram Bagian Timur. Sosialisasi berhasil dapat dilakukan secara kondusif tanpa ada pengumpulan massa sehingga kegiatan sosialisasi dapat berjalan lebih efektif dan efisien.

Berikut terdapat beberapa foto yang berhasil didokumentasikan pada saat kegiatan berlangsung: 
a. Sosialisasi upaya pencegahan penyebaran Covid-19

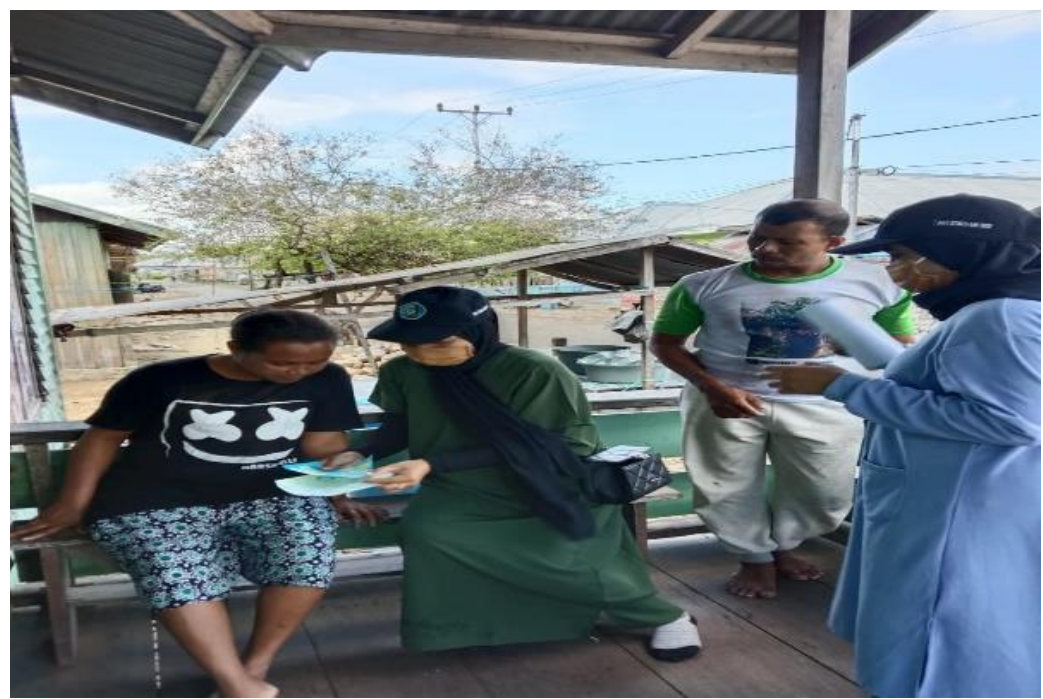

Gambar 1. Sosialisasi upaya pencegahan penyebaran Covid-19

b. Pembagian leaflet

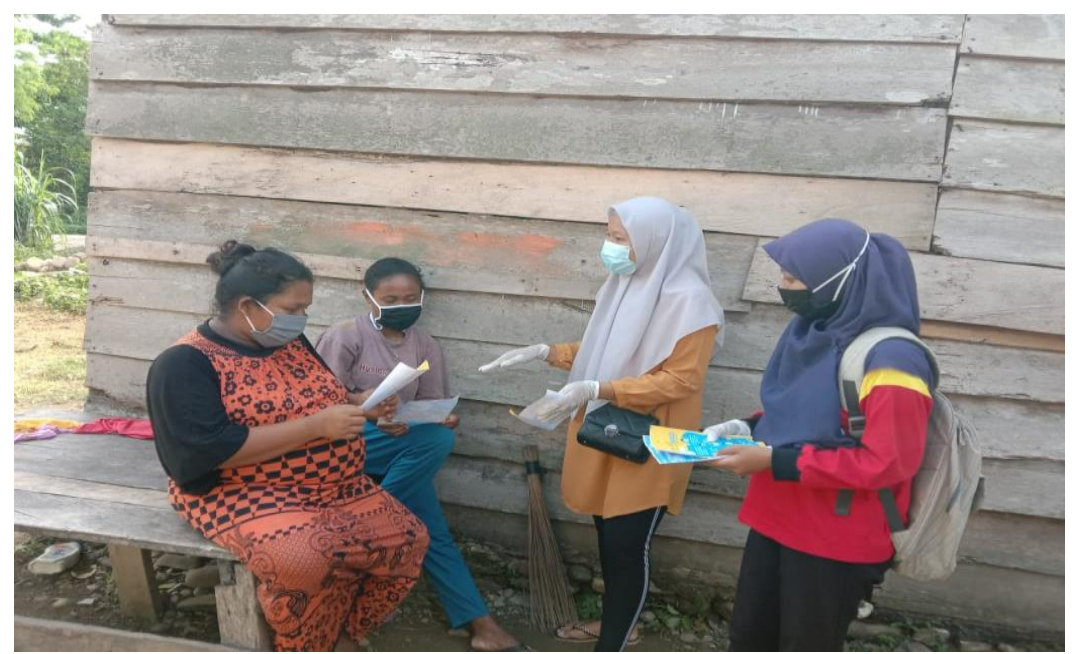

Gambar 2. Pembagian Leaflet

c. Pembagian masker

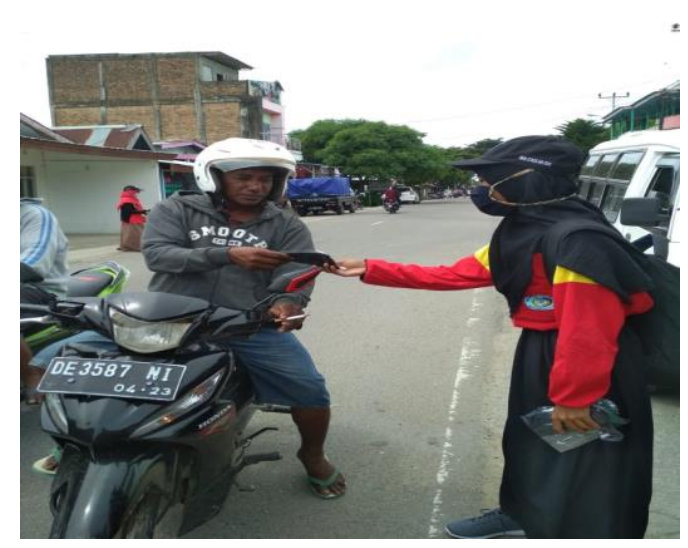

(a)

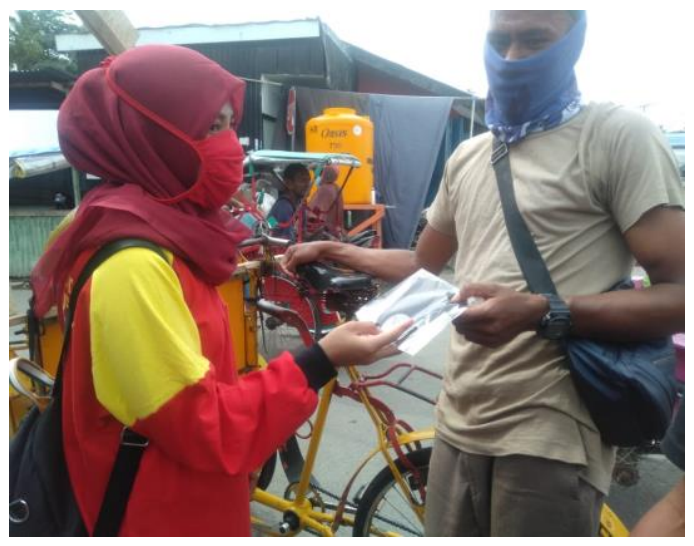

(b)

Gambar 3. Pembagian Masker (a) dan (b) di jalan raya 
d. Pembuatan tempat hand sanitizer

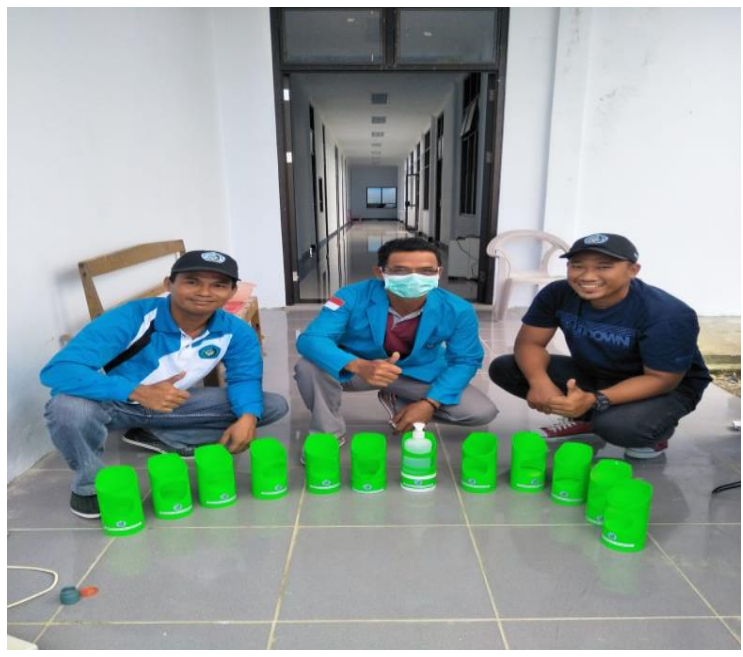

(a)

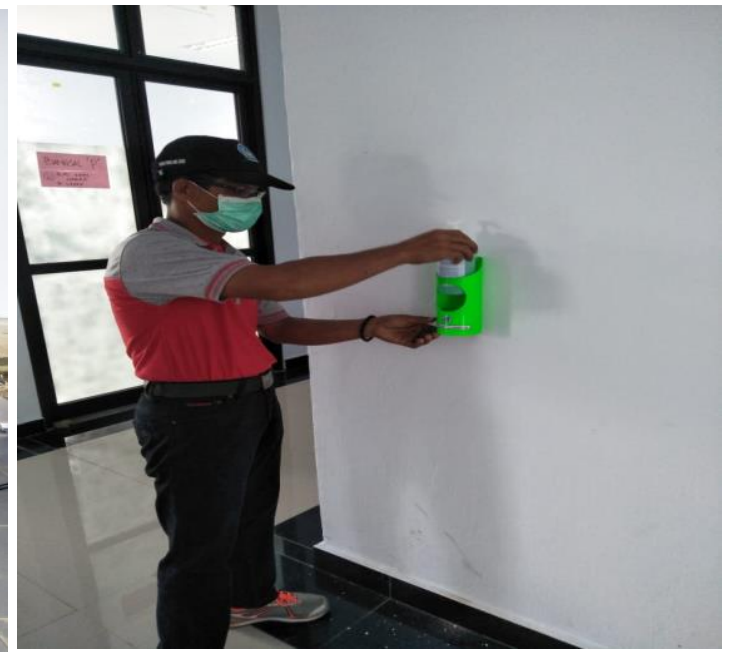

(b)

Gambar 4. (a) dan (b) Pembuatan tempat hand sanitizer

e. Pembagian hand sanitizer

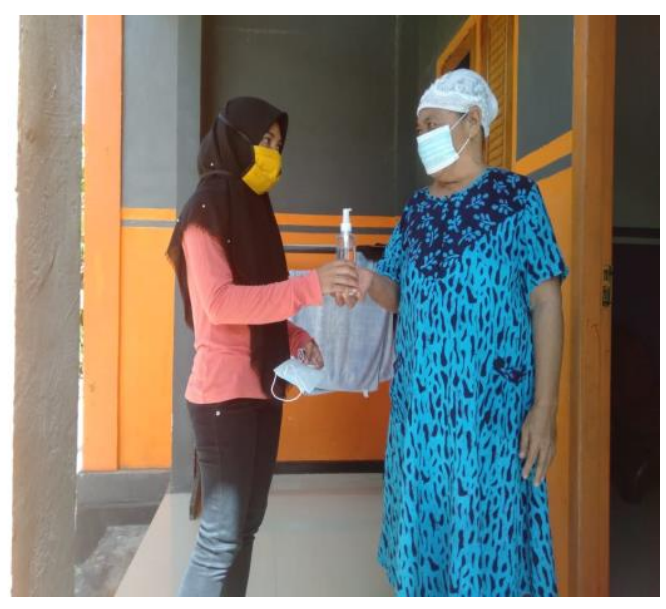

(a)

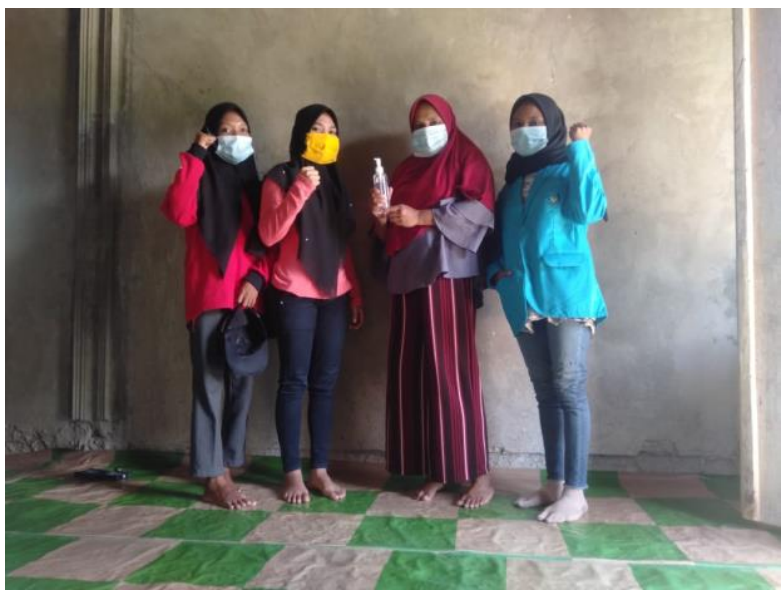

(b)

Gambar 5. (a) dan (b) Pembagian hand sanitizer

WHO mengemukakan bahwa kegiatan sosialisasi tentang pencegahan penyebaran Covid19 merupakan salah satu upaya yang dapat dilakukan [15]. Sesuai informasi dari WHO dan Kementerian Kesehatan yang menyatakan bahwa Covid-19 menyebar secara cepat melalui percikan droplet baik saat bersin/batuk maupun saat berbicara. Memakai masker menjadi salah satu cara efektif untuk menahan droplet yang menyebar saat seseorang sedang berbicara dan bersin atau batuk [6]. Terlebih masih ada Orang Tanpa Gejala (OTG) di sekitar masyarakat yang belum melakukan isolasi dengan baik. Sehingga mewajibkan masyarakat memakai masker adalah upaya terbaik untuk menurunkan risiko penularan Covid-19 [7]. Selain memakai masker, menjaga jarak dan mencuci tangan juga turut menurunkan risiko penularan Covid-19, karena jika menerapkan cuci tangan pakai sabun, risiko penularan turun dari 35\% menjadi 65\% [8]. Memakai masker kain menurunkan risiko penularan menjadi 45\%, dengan memakai masker bedah risiko penularan turun 70\% [9]. Menjaga jarak minimal 1 meter dapat menurunkan risiko penularan hingga 85\% [10]. Maka, dengan menggabungkan memakai masker dengan benar, menjaga jarak dan mencucui tangan dengan sabun, risiko penularan Covid-19 semakin rendah.

Pengetahuan dan tindakan yang nyata dari pemerintah dan masyarakat terkait PHBS akan mampu menurunkan jumlah kasus COVID-19, sehingga masa pandemi COVID-19 dapat berakhir dengan cepat [15]. Peran pemerintah harus tegas dalam menerapkan sanksi pidana dan 
pidana denda sebagai alternatif untuk membuat masyarakat jera, teredukasi dan sebagai sarana pengendalian sosial Berdasarkan fenomena tersebut, hal ini perlu disadari, pemerintah tidak bisa kerja sendiri. Perlu Gerakan massif melibatkan semua komponen masyarakat, terutama tokohtokoh nonformal yang dapat memberi pengaruh langsung ke masyarakat [1].

Sejalan dengan hal di atas ada beberapa kebijakan yang telah dilakukan oleh Pemerintah sebagai upaya memutuskan rantai penyebaran Covid-19 tersebut tentunya perlu diapresiasi karena hal tersebut merupakan bagian dari kepedulian pemerintah terhadap rakyatnya [2]. Selain itu, masyarakat juga memiliki peran penting dalam memutus mata rantai penularan COVID-19 agar tidak menimbulkan sumber penularan baru/cluster pada tempat-tempat dimana terjadinya pergerakan orang, interaksi antar manusia dan berkumpulnya banyak orang [17]. Masyarakat harus dapat beraktivitas kembali dalam situasi pandemi COVID-19 dengan beradaptasi pada kebiasaan baru yang lebih sehat, lebih bersih, dan lebih taat, yang dilaksanakan oleh seluruh komponen yang ada di masyarakat serta memberdayakan semua sumber daya yang ada. Peran masyarakat untuk dapat memutus mata rantai penularan COVID-19 (risiko tertular dan menularkan) harus dilakukan dengan menerapkan protokol kesehatan melalui perlindungan kesehatan individu dan perlindungan kesehatan masyarakat) [6].

Dengan demikian kegiatan kampanye, sosialisasi, maupun penyuluhan terkait program 3M sangat penting untuk dilakukan khususnya kepada masyarakat di desa sehingga informasi dan sosialisasi terkait Covid-19 dapat diketahui secara merata. Selain itu, BNPB mengatakan bahwa perubahan perilaku untuk menangani permasalahan penularan COVID-19, yaitu dengan mendorong percepatan perubahan perilaku masyarakat agar secara konsisten menjalankan 3M. Perubahan perilaku manusia terjadi akibat dua dorongan, yakni dorongan dari dalam diri sendiri dan dorongan dari luar. Idealnya, perubahan perilaku berasal dari kesadaran dalam diri.

\section{KESIMPULAN}

Kegiatan sosialisasi yang telah dilaksanakan untuk memutus rantai penularan Covid-19, salah satunya dengan terus menerus menerapkan 3M kepada masyarakat. Kegiatan pembagian masker, hand sanitizer, dan leaflet secara gratis, himbauan kepada seluruh masyarakat untuk menjaga jarak dan sering mencuci tangan merupakan hal-hal yang harus selalu diingat dan diterapkan oleh seluruh masyarakat Indonesia khususnya Dusun Bangoi Kabupaten Seram Bagian Timur. Informasi dan edukasi harus terus menurus diberikan kepada masyarakat, serta melakukan pengawasan agar masyarakat mau menerapkan perilaku sehat demi mengantisipasi penyebaran Covid-19. Kegiatan sosialisasi ataupun pendidikan kesehatan merupakan salah satu cara yang sangat efektif dilakukan untuk mengedukasi masyarakat.

\section{DAFTAR PUSTAKA}

[1] A. Alfiana, Wulandari, "Upaya Penguatan Ketahanan Masyarakat Desa Sirnoboyo di Masa Pandemi Covid-19," Altifani Penelit. dan Pengabdi. Kpd. Masy., vol. 1, no. 2, pp. 149-155, 2021, doi: 10.25008/altifani.v1i2.142.

[2] I. Yostuanti, "Penguatan Perilaku untuk Pencegahan Penularan Penyakit Covid-19 pada Masyarakat di Pasar Eban Kefamenanu," Pasopati, vol. 3, no. 2, pp. 80-83, 2021.

[3] E. Kartikawati, "Perspektif, Pengetahuan dan sikap Masyarakat terhadap Pandemi Covid19," PENDIPA J. Sci. Educ., vol. 5, no. 2, pp. 225-228, 2021, doi: 10.33369/pendipa.5.2.225228.

[4] D. Hardiani, H. an Yasypiaka, M. Nur Hidayat, S. Nursiah, and B. Pratama, "Sosialisasi Pentingnya Penerapan 3M di Era New Normal Desa Riding Panjang," J. Pengabdi. Masy. Indones., vol. 1, no. 3, pp. 85-90, 2021, doi: 10.52436/1.jpmi.9.

[5] E. Siringoringa, "Edukasi Pencegahan Covid-19 pada Masyarakat di Desa Paenre Lompoa Kecamatan Gantarang Kabupaten Bulukumba," Abdimas Panrita, vol. 2, no. 1, pp. 1-5, 2021.

[6] N. Asmar, Sunanda, "Pengaruh Pandemi Covid-19 bagi Masyarakat Karau Barat Kabupaten 
Bangka Tengah," Dharma Pengabdi. Perguru. Tinggi, vol. 1, pp. 11-16, 2021.

[7] S. W. Rizqi Aprilia, "Penerapan Protokol Kesehatan COVID-19 di Era New Normal Pada Kampung Tangguh Desa Karangdoro, Terminal Jajag, dan RTH Maron Genteng, Kabupaten Banyuwangi," Multidiscip. J., vol. 3, no. 1, pp. 25-33, 2020.

[8] Budiarti et al, "Edukasi Kesehatan Pencegahan Covid-19 dalam Perubahan Pengetahuan Masyarakat Kalipecabean Sidoarjo," J. Chem. Inf. Model., vol. 53, no. 9, pp. 1689-1699, 2021.

[9] A. Mutia, Otik, "Penerapan Protokol Kesehatan Era New Normal dan Risiko Covid-19 pada Mahasiswa," Ris. Inf. Kesehat., vol. 9, no. 2, 2020, doi: 10.30644/rik.v8i2.460.

[10] S. \& Nur, "Keterlibatan Warga Negara (Civil Engagement) dalam Memutus Penyebaran Covid-19," Pros. Semin. Nas. Pendidik. FKIP Univ. Sultan Ageng Tirtayasa, vol. 47, no. 3, pp. 515-519, 2020.

[11] S. Mustopa, Budiman, "Faktor-Fakotr yang Mempengaruhi Perilaku Masyarakat dengan Kepatuhan Protokol Kesehatan 3M sebagai Upaya Pencegahan Penyakit Covid-19: Literature Review," Pros. Pertem. Ilm. Nas. Penelit. Pengabdi. Masy. II, vol. 2, no. 1, pp. 116123, 2021.

[12] M. Probolinggo, "Peran Aktif Masyarakat dalam Menanggulangi Penyebaran Covid-19 di Kecamatan Kademangan Kota Probolinggo," J. Gov. Policy Innov., vol. 1, no. April, pp. 47-56, 2021.

[13] R. Pakaya, F. Ramadhani, S. Hanapi, F. Deisi Badu, and I. Iyou, "Penerapan 3M (Memakai Masker, Mencuci Tangan, dan Menjaga Jarak) dalam Upaya Pencegahan Corona Virus Disease (Covid-19) di Desa Mohiyolo Kec. Asparaga Kabupaten Gorontalo," J. Pengabdi. Kpd. Masy. Univ. Gorontalo, vol. 3, no. 1, 2021, [Online]. Available: https://jurnal.unigo.ac.id/index.php/insancita/article/view/1415/644.

[14] A. Fernandes, "Strategi Pemerintah Dalam Upaya Pencegahan Penyebaran Covid-19 Di Kelurahan Uluindano Kecamatan Tomohon Selatan Kota Tomohon," J. Polit., vol. 10, no. 4, 2021.

[15] N. Nugrawati, N. Ekawati, and A. Wijaya, "Pendidikan Perilaku Hidup Bersih dan Sehat Masyarakat Kelurahan Pa'bundukang Kecamatan Polombangkeng Selatan Kabupaten Takalar," Wind. Community Dedication J., vol. 01, no. 02, pp. 63-68, 2020.

[16] V. L. D. Pasaribu, A. N. Syafei, A. Farhan, A. Aufaizah, C. Irani, and S. R. Firtiayani, "Pengaruh Displin Protokol Kesehatan Terhadap Pencegahan Penularan Virus Covid-19," Abdimas, vol. 2, no. 2, pp. 91-98, 2021.

[17] Rahayu, "Pemberdayaan Dukungan Keluarga dalam Meningkatkan Pemahaman Pencegahan Covid-19 di Masyarakat Jatibening," J. Antara Pengmas, vol. 3, no. 1, pp. 150$154,2020$. 